\title{
HMG-COA REDUCTASE INHIBITION BY SIMVASTATIN REDUCES NEOINTIMAL INFLAMMATION IN A RAT MODEL OF ATHEROSCLEROSIS
}

\author{
REZINA SULTANA', MD SAYEDUR RAHMAN², NARGIS AKHTER ${ }^{3}$ \\ ${ }^{1}$ Assistant Professor, Department of Pharmacology \& Therapeutics, Z. H. Sikder Women's Medical College, Dhaka. \\ ${ }^{2}$ Professor, Department of Pharmacology, Bangabandhu Sheikh Mujib Medical University, Shahbag, Dhaka. \\ ${ }^{3}$ Professor, Department of Pharmacology, Bangabandhu Sheikh Mujib Medical University, Shahbag, Dhaka.
}

\begin{abstract}
Background: Inhibitors of HMG-COA-reductase reduce cardiovascular mortality through the mechanisms yet elucidated. Most ischemic events are secondary to disruption of atherosclerotic plaques highly infiltrated by macrophages. Objectives: To study the effect of the 3-hydroxy-3methyl-glutaryl coenzyme $A$ (HMG-CoA)-reductase inhibitor simvastatin on the potential mechanisms involved in the recruitment of monocytic cells into the vessel wall. Methodology: This experimental study was carried out in the Laboratory of the Department of Pharmacology \& Therapeutics, BSMMU, Shahbag, Dhaka, during the period from $1^{\text {st }}$ July 2008 to $30^{\text {th }}$ June 2009. Fifty healthy Long-Evans Norwegian male rats aged between 3-4 monthes and weighing between 180 -200gm were randomly selected and divided into 3 groups $(A, B \& C)$. Control group $A(n=10)$ were fed on standard rat diet for 8 weeks, Vechicle fed group $B(n=10)$ were fed soybean oil at a dose of $1 \mathrm{ml}$ once daily for 8 weeks and $2 \%$ cholesterol fed group $C(n=30)$ were fed a $2 \%$ cholesterol enriched diet (suspention of cholesterol powder in soybean oil) at a dose of $100 \mathrm{mg} / \mathrm{ml}$ of $2 \mathrm{ml}$ once daily for 8 weeks. After 8 weeks 10 rats of each group were sacrificed and remaining 20 rats of group $C$ were continued to the part II of the experiment and divided into two groups. Group-I (cholesterol fed control group, $n=10$ ) and Group-II (simvastatin treated group). Group-I fed $0.5 \mathrm{ml}$ of $0.1 \%$ cholesterol enriched diet once daily to maintain atherosclerotic state \& Group-II treated with $1 \mathrm{ml}$ of $60 \mathrm{mg} / \mathrm{ml}$ simvastatin at a dose of $300 \mathrm{mg} / \mathrm{Kg} /$ day along with $0.5 \mathrm{ml}$ of $0.1 \%$ cholesterol enriched diet. After 8 weeks all the rats of two group were sacrified. Blood collected from each rats for estimation of serum lipid profile by enzymatic methods and aorta was preserved for histopathological examination and Intima-media ratio was measured using Image-proplus software (Silva et al, 2000). Results: Simvastatin induced a significant reduction in serum lipids $(p<0.001)$ and in atherosclerotic lesion size $(p<0.001)$. Aortic macrophage infiltration was abolished by the treatment. Conclusions: In a rat atherosclerosis model, simvastatin diminished the neointimal inflammation and this could contribute to the stabilization of the atherosclerotic plaque. This may be an additional explanation for the reduction of acute ischemic events in patients treated with statins.
\end{abstract}

Keywords: Cholesterol, Simvastatin, Atheroschelorosis, HMG-CoA-reductase.

(Bangladesh J Physiol Pharmacol 2012;28(1\&2):5-9)

\section{INTRODUCTION}

Cholesterol-lowering drugs slow the progression of coronary atherosclerosis and diminish the incidence of ischemic event. ${ }^{1}$ Moreover, the inhibitors of the 3hydroxy-3methyl-glutaryl-coenzyme A (HMG-CoA)reductase also reduce total and coronary mortality, both in secondary and in primary prevention., ${ }^{2,3}$

Acute ischemic events are mainly secondary to plaque disruption and thrombosis. Although it is well

Address for correspondence: Dr. Rezina Sultana, Assistant Professor, Department of Pharmacology \& Therapeutics, Z.H. Sikder Women's Medical College, Dhaka. E-mail: rsultana401@gmail.com; Mobile: +8801711908588 known that lipid-rich plaques are more prone to rupture, the mechanisms by which HMG-CoA-reductase inhibitors reduce coronary events and not completely understood. Macrophage infiltration has been related to unstable coronary syndromes, probably because these cells secrete proteolytic enzymes which weaken the cap of the lesion. ${ }^{4,5}$

The purpose of this study was to determine the effect of the HMG-CoA-reductase inhibitor simvastatin on the neointimal content of macrophages in an experimental model of atherosclerosis in rats. 


\section{METHODOLOGY}

This experimental study was carried out in the Laboratory of the Department of Pharmacology \& Therapeutics, BSMMU, Shahbag, Dhaka, during the period from $1^{\text {st }}$ July 2008 to $30^{\text {th }}$ June 2009. Fifty healthy Long-Evans Norwegian male rats aged between 3-4 months and weighing between 180-200gm were randomly selected and divided into 3 groups $(A, B \& C)$. Control group $A(n=10)$ were fed on standard rat diet for 8 weeks, Vehicle fed group B $(n=10)$ were fed soybean oil at a dose of $1 \mathrm{ml}$ once daily for 8 weeks and $2.0 \%$ cholesterol fed group C $(n=30)$ were fed a $2.0 \%$ cholesterol enriched diet (suspension of cholesterol powder in soybean oil) at a dose of $100 \mathrm{mg} / \mathrm{ml}$ of $2 \mathrm{ml}$ once daily for 8 weeks. After 8 weeks 10 rats of each group were sacrificed and remaining 20 rats of group $C$ were continued to the part II of the experiment and divided into two groups. Group-I (cholesterol fed control group, $\mathrm{n}=10$ ) and Group-II (simvastatin treated group). Group-I fed $0.5 \mathrm{ml}$ of $0.1 \%$ cholesterol enriched diet once daily to maintain atherosclerotic state \& Group-II treated with $1 \mathrm{ml}$ of $60 \mathrm{mg} / \mathrm{ml}$ simvastatin at a dose of $300 \mathrm{mg} / \mathrm{Kg} /$ day along with $0.5 \mathrm{ml}$ of $0.1 \%$ cholesterol enriched diet. After 8 weeks all the rats of two group were sacrificed. All the sacrifice was done under anesthesia with chloroform. Blood from each rat was collected from carotid artery for measurement of serum lipid profile by enzymatic method and the aorta was separated from the surrounding viscera, inner thoracic \& abdominal wall and dissected out to preserved for histopathological study. ${ }^{6}$ Morphological study of the aorta was done under microscope after preparation \& staining of the aortic tissue slide ${ }^{7}$. Intima-media ratio was measured using Image-proplus software ${ }^{6}$.

All the data obtained from the experiments have been expressed as mean + standard deviation (mean + $\mathrm{SD}$ ). One-way analysis of variance (ANOVA) followed by Bonferroni test was used for comparisons between groups. Statistical significance was accepted at the level of $5 \% \quad(p<0.05)$. Statistical analysis was performed using SPSS software version 16 for windows.

\section{RESULTS}

Part-I of the experiment was carried out to determine the effect of 8 weeks feeding of $2.0 \%$ cholesterol diet on the lipid profile (Table I) and morphology of aortic tissue of rat (Table II).

Table I

Effect of $2.0 \%$ cholesterol feeding for 8 weeks on lipid profile of rats.

\begin{tabular}{|c|c|c|c|c|c|}
\hline \multirow[t]{2}{*}{ Variable } & \multicolumn{5}{|l|}{$\begin{array}{l}\text { Groups } \\
(n=30)\end{array}$} \\
\hline & $\begin{array}{l}\text { Group A } \\
(n=10)\end{array}$ & $\begin{array}{l}\text { Group B } \\
(n=10)\end{array}$ & $\begin{array}{l}\text { Group C } \\
(n=10)\end{array}$ & F value & P value \\
\hline $\begin{array}{l}\text { Serum } \\
\text { Cholesterol (mg/dl) }\end{array}$ & $77.66 \pm 1.09$ & $78.90 \pm 1.21$ & $186.42 \pm 3.13^{* *}$ & 9330.12 & $<0.001^{*}$ \\
\hline $\begin{array}{l}\text { Serum } \\
\text { Triglycerides (mg/dl) }\end{array}$ & $65.31 \pm 0.98$ & $65.23 \pm 1.13$ & $130.70 \pm 2.26^{* *}$ & 5770.50 & $<0.001^{*}$ \\
\hline $\begin{array}{l}\text { Serum HDL } \\
\text { Cholesterol (mg/dl) }\end{array}$ & $45.38 \pm 0.73$ & $45.13 \pm 0.90$ & $34.32 \pm 1.06^{* *}$ & 479.97 & $<0.001^{*}$ \\
\hline $\begin{array}{l}\text { Serum LDL } \\
\text { Cholesterol (mg/dl) }\end{array}$ & $19.06 \pm 1.54$ & $20.73 \pm 1.35$ & $125.96 \pm 4.23^{* *}$ & 5081.14 & $<0.001^{*}$ \\
\hline $\begin{array}{l}\text { Serum LDL }-\mathrm{HDL} \\
\text { ratio }\end{array}$ & $0.41 \pm 0.03$ & $0.45 \pm 0.03$ & $3.48 \pm 0.16^{* *}$ & 3190.71 & $<0.001^{*}$ \\
\hline
\end{tabular}

Table II

Effect of $2.0 \%$ cholesterol feeding for 8 weeks on morphology of aortic tissue of rats.

\begin{tabular}{l|lllll}
\hline Variable & $\begin{array}{l}\text { Groups } \\
(\mathbf{n = 3 0 )}\end{array}$ & & & & \\
\cline { 2 - 7 } & $\begin{array}{l}\text { Group A } \\
(n=10)\end{array}$ & $\begin{array}{l}\text { Group B } \\
(n=10)\end{array}$ & $\begin{array}{l}\text { Group C } \\
(n=10)\end{array}$ & F value & P value \\
$\begin{array}{l}\text { intima-media ratio of } \\
\text { aorta }\end{array}$ & $\begin{array}{lllll} \\
0.52 \pm 0.01\end{array}$ & $0.54 \pm 0.01$ & $2.15 \pm 0.04^{* *}$ & 11874.45 & $<0.001^{*}$ \\
\hline
\end{tabular}

In experiment-I there was marked increase in serum cholesterol level \& intima-media ratio of aorta in the $2.0 \%$ cholesterol fed group (C) as compared to control group A and soybean oil fed group B and the rise was highly significant $(p<0.001)$. 
HMG-COA Reductase Inhibition by Simvastatin Reduces Neointimal Inflammation in a Rat Model of Atherosclerosis

Table III

Effect of Simvastatin treatment on serum lipid profile of $2.0 \%$ cholesterol fed rats.

\begin{tabular}{|c|c|c|c|c|}
\hline \multirow[t]{2}{*}{ Variable } & $\begin{array}{l}\text { Groups } \\
(n=20)\end{array}$ & & & \\
\hline & $\begin{array}{l}\text { Group I } \\
(n=10)\end{array}$ & $\begin{array}{l}\text { Group II } \\
(n=10)\end{array}$ & F value & P value \\
\hline Serum Cholesterol (mg/dl) & $123.93 \pm 1.53$ & $93.35 \pm 3.47^{* *}$ & 400.49 & $<0.001^{*}$ \\
\hline Serum Triglycerides (mg/dl) & $112.28 \pm 2.56$ & $82.96 \pm 2.20^{* *}$ & 322.47 & $<0.001^{*}$ \\
\hline $\begin{array}{l}\text { Serum HDL Cholesterol } \\
(\mathrm{mg} / \mathrm{dl})\end{array}$ & $37.14 \pm 1.06$ & $45.94 \pm 1.06^{* *}$ & 170.44 & $<0.001^{*}$ \\
\hline $\begin{array}{l}\text { Serum LDL Cholesterol } \\
(\mathrm{mg} / \mathrm{dl}) \\
\text { Serum LDL - HDL ratio }\end{array}$ & $\begin{array}{l}64.43 \pm 2.26 \\
1.73 \pm 0.10\end{array}$ & $\begin{array}{l}30.81 \pm 3.85^{* *} \\
0.66 \pm 0.09^{* *}\end{array}$ & $\begin{array}{l}370.84 \\
400.02\end{array}$ & $\begin{array}{l}<0.001^{*} \\
<0.001^{*}\end{array}$ \\
\hline
\end{tabular}

Table IV

Effect of Simvastatin treatment on morphology of aortic tissue of $2.0 \%$ cholesterol fed rats.

\begin{tabular}{l|llll}
\hline Variable & $\begin{array}{l}\text { Groups } \\
(\mathbf{n}=\mathbf{2 0})\end{array}$ & & \\
\cline { 2 - 5 } & $\begin{array}{l}\text { Group I } \\
(\mathrm{n}=10)\end{array}$ & $\begin{array}{l}\text { Group II } \\
(\mathrm{n}=10)\end{array}$ & F value & P value \\
\hline intima-media ratio of aorta & $2.29 \pm 0.02$ & $1.61 \pm 0.01^{* *}$ & 1721.47 & $<0.001^{*}$ \\
\hline
\end{tabular}

Part-II of the experiment was carried out to determine the effects of 8 weeks feeding of $2.0 \%$ cholesterol diet followed by another 8 weeks feeding of $0.1 \%$ cholesterol diet with simvastatin treatment on the lipid profile (Table III) and morphology of aortic tissue of rat (Table IV).

In experiment-II there were marked decrease in serum cholesterol level and intima-media ratio of aorta in simvastatin treated group (II) as compared to cholesterol fed control group (I) and the change were highly significant $(p<0.001)$.

\section{HISTOPATHOLOGICAL EXAMINATION}

Hisopathological Examination of thoracic aorta specimen of $2.0 \%$ cholesterol fed rats under microscope showing narrowing of the lumen of aorta due to gross atherosclerotic plaque in sub endothelial region. There were foam cells, inflammatory cells and fat leaden smooth muscle cells found in sub endothelial region. Middle layer (Media) of the aorta was thin (Figure-1).

After Simvastatin treatment there were no foam cells, inflammatory cells and fat leaden smooth muscle cells in sub endothelial region of aorta. Thickness of the middle layer of the aorta was increased. The intima and media region are resembling near normal (Figure-2). 


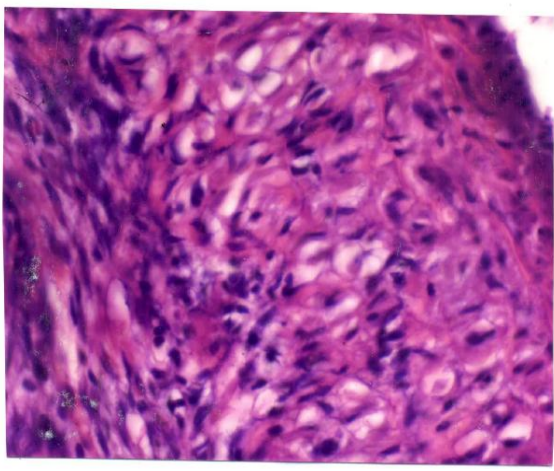

Figure 1

Photomicrograph showing histological cross-section of thoracic aorta specimen of rat fed a $2.0 \%$ cholesterol-enriched diet for 8 weeks. Magnification (X40)

\section{DISCUSSION}

The present work has demonstrated that in a rat model of atherosclerosis the HMG-CoA-reductase inhibitor simvastatin reduces the inflammatory component in the atherosclerotic lesion. This effect could help to explain the reduction in ischemic event observed upon statin treatment in clinical trials.

Simvastatin decreases serum cholesterol, triglyceride, LDL-C \& increase HDL-C level, which resembles to the findings of few other studies. ${ }^{8,9}$ Hypolipidaemic benefit of simvastatin in this study is due to its inhibitory effect on HMG-CoA-reductase and mevalonic acid which are essential for cholesterol synthesis. $^{9}$

It is well known that acute ischemic events are usually due to the rupture of unstable plaques independently of their size. ${ }^{4}$ In our model, treatment with simvastatin resulted in the abolition of macrophage infiltration. It must be emphasized that simvastatin treatment was not started at the beginning of the experiment but after 8 weeks of hyperlipidemic diet, in an attempt to imitate the conditions of human atherosclerosis, where statins are used in most cases once atherogenesis has begun.

Most thromboses of vessels with atherosclerotic lesions are preceded by a fissure that allows the lipid core to contact the circulating blood. $^{10,11}$ An inflammatory reaction plays an important role in this rupture, and the presence of macrophages in the surroundings of the fissured plaques from patients with acute coronary syndromes has also been demonstrated. ${ }^{4,5}$ These cells can release proteolytic enzymes that degrade the fibrotic cap of the lesion, making it prone to rupture. ${ }^{12}$ The presence of macrophages in the lesion is favoured by chemoattractants such as oxidized low density lipoprotein (OX-LDL) and MCP-I. In this sense, the lipid lowering effect of simvastatin would not only reduced the generation of OX-LDL but also the synthesis of MCP-

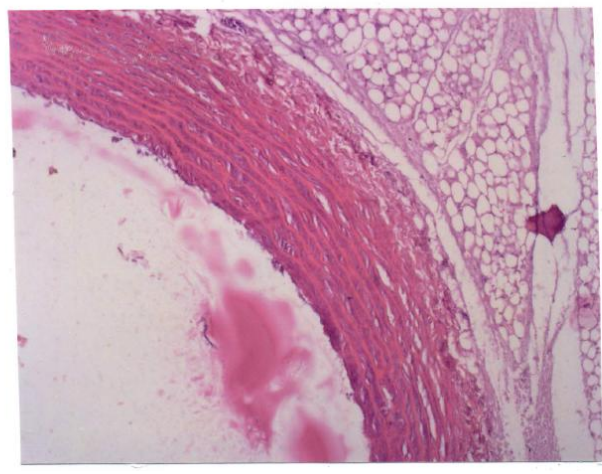

Figure 2

Photomicrograph showing histological cross-section of thoracic aorta specimen of rat fed $2.0 \%$ cholesterol diet for 8 weeks then treated with Simvastatin for another 8 weeks. Magnification (X10)

I (Monocyte chemoattractant protein-I). This chemokine is present in human atherosclerotic lesions, mainly in the areas infiltrated by macrophages. ${ }^{3,14}$ Simvastatin has some additional mechanisms involved in the neointima infiltration, such as the expression of adhesion molecules and other chemokines T.

This study shows simvastatin treated group, the histopathological examination of aorta revealed that there were no foam cells, inflammatory cells and fat leaden smooth muscle cells in subendothelial region and increase the thickness of middle layer of the aorta which might be due to inhibition of fibrinogen induced smooth muscle cell proliferation and migration ${ }^{15}$ and reduced expression of proinflammatory cytokines and chemokines $^{16}$ and reverse endothelial disfunction by prevention of LDL-Oxidation and increase NO bioavalibility. ${ }^{17}$

In this study, decrease in intima-media ratio of the aorta in simvastatin treated group. This may be due to anti-inflammatory actions, property to reverse endothelial dysfunction by prevention of LDL-Oxidation, stabilize atheromatus plaques by reducing the lipid core, inhibiting inflammation increasing collagen production, altering smooth muscle cell accumulation and suppressing angiogenesis in the atheromatous plaque which is similar to the other studies. ${ }^{18}$

\section{CONCLUSION}

As a whole, our results demonstrate that simvastatin reduces the inflammatory features in the neointima and suggest a potential explanation for the reduction of ischemic event observed with HMG-CoAreductase inhibitors in clinical trials. They also indicate that a part of this effect could be due to a direct action of this drug on the atherosclerotic lesions, although further work is needed to evaluate its contribution. 


\section{REFERENCES}

1. Brown BG, Fuster V. Impact of management in stabilization of coronary disease. In: Fuster V, Ross R and Topol EJ, ed. Atherosclerosis and Coronary Artery Disease. Philadelphia: Lippincott-Raven, 1996: 191-205.

2. The $4 \mathrm{~s}$ Investigators. Randomized trial of cholesterol lowering in 4444 patients with coronary heart disease: the Scandinavian Simvastatin Survival study (4S). Lancet 1994;344:1383-9.

3. Shepherd J, Cobbe SM, Ford I, et al. Prevention of coronary heart disease with pravastatin in men with hypercholesterolemia. N Engl J Med 1995;333:1301-7.

4. Van der Wal AC, Becker AE, Van der Loos CM, Das PK. Site of intimal rupture or erosion of thrombosed coronary atherosclerotic plaques is characterized by an inflammatory process irrespective of the dominant plaque morphology. Circulation 1994:89:36-44.

5. Moreno PR, Falk E, Palacios IF, Newell JB, Fuster V, Fallon JT. Macrophage infiltration in acute coronary syndromes: implication for plaque rupture. Circulation 1994;90:775-8.

6. Islam MZ, Rahman MS. Comparative study of hydrochlorothiazide and indapamide on the anti-atherogenic potential of losartan in cholesterol fed rat. BMRC Bulletin 2010: 36(1): 14-19.

7. Stary $\mathrm{HC}$, Chandler $\mathrm{AB}$, Dinsmore RE, Fuster $\mathrm{V}$, Glagov $\mathrm{S}$, Insull $W$ Jr, et al. A definition of advanced types of atherosclerotic lesions and a histological classification of atherosclerosis. A report from the committee on vascular lesions of the council on arteriosclerosis, American Heart Association. Circulation 1995; 92: $1355-74$

8. Ballantyne CM. Cholesterol, lipids, and statins. Tex Heart Inst J. 2005 ; 32: 378-79.

9. Cheng AY, Leiter LA. Implications of recent clinical trials for the National Cholesterol Education Program Adult Treatment Panel III guidelines. Curr Opin Cardiol. 2006; 21:400-04.
10. Fuster V, Badimon L, Badimon JJ, Chesebro JH. The pathogenesis of coronary artery disease and the acute coronary syndromes. N Engl J Med 1992;326:242-50.

11. Fernandez-Ortiz A, Badimon JJ, Falk E, et al. Characterization of the relative thrombogenicity of atherosclerotic plaque components: Implications for consequences of plaque rupture. J Am Coll Cardiol 1994;23:1562-9.

12. (15) Galis ZS, Sukhova GK, Lark MW, Libby P. Increased expression of matrix-metalloproteinases and matrix-degrading activity in vulnerable regions of human atherosclerotic plaques. ] Clin Invest 1994:94:2493-503.

13. Yia-Herttuala S, Lipton BA, Rosenfeld ME, et al. Expression of monocyte chemoattractant protein-1 in macrophage rich areas of human and rabbit atherosclerotic lesions. Proc Natl Acad Sci. USA 1991;88:5252-6.

14. Neikel NA, Coughlin SR, Gordon D, Wilcox JN. Monocyte chemoattractant protein-1 in human atheromatous plaques. J Clin Invest 1991;88:1121-7

15. Lee TS, Chang CC, Zhu Y, Shyy JY. Simvastatin induces heme oxygenase-1: A novel mechanism of vessel protection. Circullation. 2004; 110: 1296-1302.

16. Dichtl W, Dulak J, Frick $M$, Alber HF, Schwarzacher SP, Ares MP et al. HMG-CoA reductase inhibitors regulate inflammatory transcription factors in human endothelial and vascular smooth muscle cells. Arteriscler Thromb Vasc Biol. 2003; 23: 58-63.

17. Landmesser $U$, Engberding N, Bahlmann Fh, Schaefer A et al Statin-induced improvement of endothelial progenitor cell mobilization, myocardial neovascularization, left ventricular function, and survival after experimental myocardial infraction requires endothelial nitric oxide synthesis. Circulation 2004; 110: 1933-39.

18. Tandon V, Bano G, khajuria V, Parihar A, Gupta S. Pleiotropic effects of statins. Indian J Pharmacol. 2005; 37: 77-85. 